\title{
Lighting The Darwin Fuse
}

In 1923, Rev. William Bell Riley painted a frightening picture for his congregation at the Minneapolis First Baptist Church. Delivered to some two thousand church members, Riley's sermon depicted the fruits of teaching atheistic evolution in Soviet Russia. ${ }^{1}$ Inspired by Darwinism and a Marxist conception of social evolution, Bolshevik leaders had embarked on an immoral transformation of Russian society. "There isn't a single one of the civilities of the Christian civilization that this [Soviet] rule cares to retain," Riley charged. "They have deliberately attempted to destroy the family, to governmentize all women, and compel every babe that is born to be a bastard." This ruthless Soviet policy constituted Act One of the "Darwinian drama," with "survival of the fittest" taking center stage. Fueled by jungle ethics, the amoral Bolsheviks aimed to take over the world and had placed "secret agents of Lenine" in New York. They were planting "dynamite at many American points," saving their "largest charges" for the public schools. Those "charges" consisted of textbooks employing God-denying evolutionary arguments. Having planted such volatile 
materials, the clandestine communists would "light the Darwin fuse and witness the demolition." 2

There was a large dose of fantasy in Riley's conspiratorial fears. But his sermon was correct in the claim that Marx and Engels supported Darwin. It was equally true that leaders of the pre-World War I Socialist Party of America promoted evolutionary science. They freely combined social and biological evolutionary arguments, mixing Marx and Herbert Spencer. After the Great War, the fledgling American communist parties took up the evolutionary cause. Their leaders made an uncompromising stand in defense of evolution, aiming to clarify for revolutionary workers what was at stake in the 1925 "Monkey Trial" of John Scopes. American communists were in step with their Russian counterparts, who promoted both atheism and "Marxist Darwinism" and paid close attention to American developments. ${ }^{3}$ The Bolshevik regime did not "governmentize" women, but it did carry out an ambitious program of raising women's power and status. Over the next century, when American fundamentalists and antievolutionists linked evolution to communism and immorality, their claim was based not only on imagined conspiracies but on the real promotion of evolutionary science, atheism, and social change by socialists and communists both in the US and abroad.

The association between evolutionary science and Marxism began in the wake of Darwin's publication of On the Origin of Species. In December 1859, Friedrich Engels wrote to Karl Marx, "Darwin, whom I am just reading, is splendid." 4 A year later, after Marx finished the book himself, he wrote back to Engels, "This is the book which contains the basis in natural history for our view." ${ }^{5}$ Marx and Darwin shared a basic materialist outlook. At the same time, Marx and Engels did fault Darwin for applying pro-capitalist economics to nature. ${ }^{6}$ As Marx wrote in 1862, "It is remarkable how Darwin rediscovers, among the beasts and plants, the society of England with its division of labour, competition, opening up of new markets, 'inventions' and Malthusian 'struggle for existence." " ${ }^{7}$ By transposing mid-nineteenth-century capitalist England onto the natural world, Darwin was some variant of what came to be called a "social Darwinist."

The founders of the modern communist movement, although not unqualified endorsers of Darwin, continued to pay tribute to him. ${ }^{8}$ In 1873 , 
Marx sent Darwin an inscribed copy of the second volume of Capital signed by a "sincere admirer." ${ }^{9}$ In 1877, Engels published Anti-Dühring, whose chapter on "The Organic World" featured a spirited defense of Darwin. ${ }^{10}$ As more and more German socialists promoted Darwin's ideas, the prominent anti-Darwinist scientist Rudolf Virchow publicly attacked Darwinism, as leading to socialism. German Darwinist Ernst Haeckel strenuously denied this, prompting Darwin himself to decry "the foolish idea ... on the connection between Socialism and Evolution through Natural Selection." And yet at Marx's funeral in 1883, a year after Darwin's death, Engels eulogized, "Just as Darwin discovered the law of development of organic nature, so Marx discovered the law of development of human history." 11

That law of development and its evolutionary character stood at the center of The Origin of the Family, Private Property, and the State, which Engels published the following year. Engels showed how these central institutions of modern capitalist society, far from being eternal or God-given, were of recent historical vintage. They emerged only as human society evolved from "savagery" (bands of hunters and gatherers) to "barbarism" (settled agricultural existence) to "civilization" (modern capitalist society). He concluded that in the earliest phase of this stagewhich Engels called the "childhood of the human race"-our ancestors must have been tree-dwelling, apelike creatures who evolved the capacity of "articulate speech" over thousands of years. ${ }^{12}$ Once modern humans had evolved, Engels argued, they lived in a condition of "primitive communism." Women held considerable social power through the institution of matrilineal descent. Humans lived in a relationship of rough equality. It was the emergence of class divisions-made possible by the production of a social surplus - that paved the way for the oppression of women, political tyranny, and economic exploitation. These evils were not a product of human nature, but of class society. Once modern class society was overthrown, humanity could restore the virtues of "primitive communism" but on a higher material level.

Along with Marx and Engels themselves, the other major influence on American socialists and reformers writing and speaking on evolutionary themes was Herbert Spencer. Author of the phrase "survival of the fittest," Spencer is best known today as an ultra-individualist who opposed government aid to the poor and thought socialism was tantamount to 
"slavery." But Socialists embraced not his reactionary book Man against the State (1894), written near the end of Spencer's life, but the younger, radical-minded opponent of the English landed aristocracy and established church. ${ }^{13}$ Then a critic of individual landownership and supporter of women's suffrage, Spencer argued that, freed of government interference, and under Malthusian population pressure, society would evolve toward a perfect "equilibration" between the social organism and its environment.

Spencer drew heavily on a vision of evolution associated with JeanBaptiste Lamarck that revolved around the inheritance of acquired characteristics. Lamarck thought that generations of giraffes gained longer necks by straining to reach leaves higher up in trees and passing on those longer necks to offspring. Spencer likewise believed that humans could improve the "fitness" of society by conscious effort during their lifetimes. In contrast, Darwin's proposed mechanism of natural selection did not depend on conscious striving. It only required that some members of a natural population were more successful than others in passing on their genetic material, thereby changing the profile of that population over long periods of time. More Lamarckian than Darwinian, Spencer's First Principles (1862) laid out the beginnings of his "synthetic" philosophy that combined physical, biological, social, mental, and political development into one grand evolutionary scheme. Concluding his chapter on "equilibration," Spencer averred that "evolution can end only in the establishment of the greatest perfection and the most complete happiness." 14

It is appropriate that Spencer's ashes were deposited in London's Highgate Cemetery, facing the grave of Karl Marx, since early American socialist writers attempted to incorporate both men's work into their reckonings with evolutionary science. They were influenced by prominent Italian socialist and criminologist Enrico Ferri, who called for a "class struggle in the Darwinian sense," thus blurring the lines between social and biological evolution. ${ }^{15}$ Ernest Untermann, a German-born American Socialist activist with university training in paleontology, geology, and biology, wrote widely on the relationship between socialist politics and science and was the translator of Engels's Origin into English. Identifying himself as a "socialist Darwinian," Untermann published Science and Revolution in 1905, one of the most notable attempts to wed Marxism and the 
Darwinian science of the day. He was well aware that Marx and Engels themselves maintained a clear line between the two. But he also claimed that a "dialectic synthesis of Marxism, Darwinism and Spencerism" was allowed. ${ }^{16}$

More critical of Spencer but still enamored of the organic analogy was Chicago Socialist Arthur Morrow Lewis. Born in England, educated through the common schools, and trained as a molder, the largely self-taught Lewis became a highly effective popularizer of socialist evolutionism to an American working-class audience. ${ }^{17}$ Lewis regularly delivered lectures on science to overflow crowds on Sunday mornings at Chicago's Garrick Theater. He debated in open-air meetings on a variety of topics, including science and socialism. ${ }^{18}$ In 1908, Charles H. Kerr \& Co., the best-known American publisher of socialist literature, issued a compilation of Lewis's lectures as Evolution: Social and Organic. ${ }^{19}$ In his preface, Lewis observed that some Socialists had questioned the wisdom of lecturing on evolution, fearing that challenging workers' prevailing religious notions would result in "driving people away." In response, Lewis wrote that "I have yet to be convinced that there is any kind of knowledge which is good for university men, but unfit for workingmen."20

The knowledge Lewis sought to impart to Chicago's working people concerned both their past and their future. Lewis traced the origin of evolutionary ideas to the ancient Greek materialist philosophers-among them Thales, Heraclitus, and Empedocles-who provided, in Spencer's words, "vague adumbrations" of future evolutionary science. Noting that scientific knowledge was carried forward during the Middle Ages by "pagan Arabians" and not Europeans, he credited the rising capitalist class_in its progressive phase-as the "harbinger" of progress, bringing to the fore thinkers such as Linnaeus, Lyell, and Lamarck. But, echoing Marx, Lewis argued that by unleashing the forces of modern science, the capitalists planted the seed of their own destruction. Realizing this, today's plutocrats would rather "suppress science or at least prevent its reaching the proletarian brain." Yet, they rely on a mode of production that makes the education of workers "a relentless necessity" and thus are caught in a painful contradiction. ${ }^{21}$

One mark of the seriousness with which Lewis took his educational task is his engagement with recent trends in evolutionary science. Even as 
he trumpeted Darwin's central explanatory concept of natural selection, Lewis was well aware that Darwinism in the early twentieth century faced a range of challenges that evolutionists could not yet effectively meet. Fleeming Jenkin had posed problems with Darwin's concept of heredity, and Lord Kelvin's lowered estimates of the age of the earth seemed to make an imperceptibly slow process of natural selection impossible. ${ }^{22}$ Meanwhile, the rediscovery of Gregor Mendel's work in genetics initially led pioneer geneticists Thomas Hunt Morgan, Hugo de Vries, and others to argue against gradual Darwinian natural selection. They preferred a theory of rapid evolutionary leaps, known as mutation theory. ${ }^{23}$ Then there was August Weismann and his mice. A German zoologist who was determined to disprove the Lamarckian concept of the inheritance of acquired characteristics, Weismann cut off the tails of mice, bred five generations of offspring, and found that they all had intact tails, rather than the stubby ones as Lamarck would have predicted. Since Lamarck's ideas were still popular in the early twentieth century, Weissman's results seemed to confuse the evolutionary picture even further. ${ }^{24}$

Lewis took up these challenges and wove them into his vision of socialist politics. Dutch mutation theorist Hugo de Vries conducted studies of the evening primrose (Oenothera lamarkiana), which seemed, at random, to produce differently colored varieties from the original yellow stock, thus seemingly undermining the model of gradual evolution by natural selection. Mutation theorists used these results to attack Darwinians. But as Lewis pointed out, de Vries did not deny Darwinian natural selection; rather, he was making an argument about the cause of variation, on which natural selection could act. Lewis hypothesized that species might undergo alternate periods of stability and "mutability," which would shrink the total amount of time needed for natural selection to operate. Two happy results would be that Kelvin's new estimate of the age of the earth was no longer contradicted; and gaps in the fossil record could be explained. Lewis then derived the political lesson: just as natural evolution oscillates between stasis and rapid change, so does "social development" move between periods of "apparent social stability" and those of "social revolution when the entire social superstructure is transformed." 25 Some six decades later, paleontologist Stephen Jay Gould's Marxist-influenced theory of punctuated equilibrium would make similar connections (and draw similar attention from creationists). 
Lewis also took up Weismann's Darwinian challenge. Weismann's experiments seemed to undermine a widespread optimistic belief, among reformers and many socialists, in the inevitability of a SpencerianLamarckian progress, based on continual efforts at human social betterment. If those improvements-the social equivalent of the stubby mouse tails-were not passed on to the next generation, did not the future look bleak? Not to Lewis. To the extent that the personalities of working people under capitalism were affected negatively by "degrading conditions," if their behavioral traits were passed on to future generations until they became "fixed characters," then a future socialist society that depended on the improving capacities of those same working people would be a utopian dream. ${ }^{26}$ Thanks to Weismann, the future now looked brighter. Social evolution and biological evolution could proceed on parallel but separate paths.

The problem of the relationship between social and biological evolution was posed sharply for members of the fledgling Socialist Party of America who were women. When the first German-American socialists arrived in the US at midcentury, the "woman question" was barely asked. Holding to the prevailing patriarchal view of women's role in the family, male socialists dismissed demands for women's suffrage and opposed their entry into the paid workforce. It took decades of immigration, increasing entry of women into industry, and determined organizing by early feminist socialists to put the issue on the agenda. By the early twentieth century, a new generation of women, who had earned their spurs in suffrage, temperance, and labor activism, placed their feminist stamp on the young Socialist Party, through the Women's National Committee and the Socialist Woman magazine. ${ }^{27}$

Of considerable influence on American socialists, both male and female, was Woman and Socialism (1883) by German socialist August Bebel. Published the year before Engels's Origin, Bebel's work provided a similar account of the roots of women's second-class status, reaching back to the downfall of a primitive communist matriarchy. Departing from the view that most German socialists had taken, Bebel argued that the path forward was the "release of woman from her narrow sphere of domestic life, and her full participation in public life and the missions of civilization." ${ }^{28}$ Not only did Bebel challenge the common view that 
women were ordained by nature to be intellectually inferior to men; he placed his argument in an evolutionary framework. While he agreed with Darwin that there were comparatively few known women of "genius," he disagreed that this stemmed from women's innate biological nature. Rather, Bebel argued, it was the "conditions of existence" that explained the differential social evolution of men and women. Only under socialism, he claimed, would the conditions be sufficiently changed to allow women to develop their full potential. Bebel was confident that under those conditions, which had never "existed in human evolution," "woman will rise to a height of perfection that we can hardly conceive to-day." ${ }^{29}$ In the sense that social evolution allowed for the development of all individuals' potentiality, male or female, Bebel believed that "Darwinism" was an "eminently democratic science." 30

A growing number of American Socialists were willing to consider the need for women's political and economic equality. But they were more resistant to challenging existing norms of women's sexuality. The Socialist Party did take part in anti-prostitution "social purity" campaigns in the early twentieth century and sharpened the traditional Progressive critique by focusing on the culpability of capitalism for the degradation of workingclass women. But the bohemian "new intellectual" Socialists, around publications like the Masses, New Review, and New York Call, who pioneered the movement on behalf of birth control or "family limitation," were marginalized by the older, established party leaders. It was one thing to view woman as victim, another to see her as an active subject with sexual drives and interests equal to any man. ${ }^{31}$ Intense pressures weighed on Socialists to play down aspects of their political and intellectual heritage (including Bebel's work) that might lead to charges of immorality or advocacy of "free love."

The perils of socialist evolutionism emerged in the activist life of Lena Morrow. An Illinois-born, college-educated veteran of the Woman's Christian Temperance Union (WCTU), and an energetic defender of women's rights, Morrow was a leading Socialist Party organizer who became the first woman ever elected to the party's National Executive Committee. Based in San Francisco, Morrow traveled throughout the West, visiting mining and lumber camps to boost the socialist cause. She was a fearless street speaker who in 1903 called her new husband, Socialist lecturer Arthur Morrow Lewis, to bail her out of jail. Though she supported 
women's suffrage, Lena Morrow Lewis rejected the idea that women were different from men in some fundamental way. Hewing to a Lamarckian evolutionary view, she believed that men's prejudice toward women had resulted from their "brain cells" adapting to lower economic forms, which were now being superseded. ${ }^{32}$

While Lena Morrow Lewis received socialist accolades, not all her comrades were comfortable with a woman in such a leadership role. Her short and apparently unhappy marriage to Lewis-they divorced in 1905-may have made things more difficult for her. Then there was the "scandal" that enveloped Lena Morrow Lewis in 1910-11. Articles in internal party bulletins charged that Lewis carried on an affair with Socialist Party national secretary J. Mahlon Barnes, who had himself been accused by a party rival of engaging in "free love" with office employees. ${ }^{33}$ Writing in the Masses in 1911, and perhaps reflecting on these painful events, Lena Morrow Lewis noted that, historically, women had passed from the stage of primitive communism in which they could live "the life of a human being" to class society, in which they were defined by their "maternal functions." Hence we say "man and wife" and never "husband and woman." But with the prospect of socialism, once again woman could "live the life of a complete human being." In the new society, standards of "sex relations" and of "morality" would be determined by newly evolved conditions and social demands.

If there was one socialist who embodied the evils of evolutionist immorality in the eyes of creationists during the 1920s (and generated the "Red Dynamite" label), it was the Reverend Charles Browning "Bouck" White. Hailing from an old-line New York family, White graduated from Union Theological Seminary in 1902. He served as pastor at several Congregational churches, moved to New York City, and then, under the impact of the 1909-10 shirtwaist strike and subsequent Triangle Shirtwaist Fire of 1911, became a militant socialist preacher. White first attracted headlines (and courted arrest) in May 1914 when he led a labor protest at the Calvary Baptist Church in New York City. Its congregation included John D. Rockefeller Jr., primary owner of Colorado Fuel and Iron, where private police and state militia had just carried out what came be known as the Ludlow Massacre. On the eve of US entry into World War I, White 
was again arrested. He held a church service in which flags of combatant nations, as well as the American flag, were burned in a testament to "internationalism and universal brotherhood." 34

White's writing also got him into trouble..$^{35}$ In 1911, White authored a popular biography of Jesus, The Call of the Carpenter (1911), which made a profound impact on Socialist Eugene Debs. Drawing on a nineteenth-century literary trend that portrayed Jesus as a real historical and non-divine figure, White was the first to create a book-length biography of Jesus as a proletarian revolutionary who had come of age as a young laborer in "working-class Galilee." While the book sold well, its radicalism led to White's dismissal from his position as head resident at the Holy Trinity Episcopal Church, prompting him to start his own unique denomination-the Church of Social Revolution. ${ }^{36}$

At White's new church, he attracted renewed attention by flouting prevailing notions of proper marriage. White favored a new set of vows that bound husband and wife not as long as they both shall live but "so long as love shall endure." Designed to accommodate a new ideal of "companionate marriage," the vows, said White, were for those who were "in a spirit of revolt against old customs." ${ }^{37}$ In this spirit, he married Andree Emilie Simon, a wealthy young Frenchwoman. Upon their arrival in the US in 1921, the couple briefly lived in New York City, where White hired a tutor from the Intercollegiate Socialist Society to inculcate his young bride with radical ideas. When this educational experiment failed, they removed to White's run-down Ulster County country "estate," which quickly led Simon to file for an annulment of their marriage. Rumors of White's radical notions and Simon's charges of abuse led local vigilantes to abduct, tar and feather White, and dump him on the outskirts of town. ${ }^{38}$

For all his uniqueness, White was typical of his fellow socialists in one respect: his enthusiasm for evolutionary science. In The Call of the Carpenter, White hailed evolution's ability to undermine the idea of "God the father almighty" - which he thought had been used as a weapon of class exploitation. This explained why Darwinism had been hailed by the "proletariat" and the "democracy." To show that evolution aided the forces of social revolt, White quoted representatives of the forces of social order denouncing Darwin, drawing on evidence collected in Andrew Dickson 
White's A History of the Warfare of Science with Theology in Christendom (1896). They included historian Thomas Carlyle, who called Darwin "the apostle of dirt worship," and a French Catholic apologist who claimed that the "offspring" of Darwinism were "revolutions." ${ }^{39}$ Like his socialist comrades, Bouck White reminds us that a politicized left-wing "social Darwinism" was alive and well in early twentieth-century America.

In the half century before the Bolsheviks took power in Russia in 1917, reformers and revolutionaries there also embraced Darwin. The publication of Darwin's On the Origin of Species in 1859 coincided with a period of social and political ferment, symbolized by the freeing of Russian serfs in 1861. The close alliance between the conservative Russian Orthodox Church and the czarist regime, along with the relative lack of religious "modernists," promoted an identification of science and progress by nihilists and populists. Debates raged among scholars over the precise identification of the evolutionary mechanism. Czarist universities were filled with sparring neo-Lamarckians, vitalists (who believed that evolution sprang from an inner life-force within biological organisms), Mendelians, mutation theorists, and, due to the writings of Prince Kropotkin, those who believed that "mutual aid" by members of the animal and plant kingdoms was the primary vehicle for change.

But for the vast majority of Russian intellectuals, a common origin for all life on earth was not seriously in doubt. In 1909, they marked the centenary of Darwin's birth with conferences and a multi-authored volume of tribute, In Memory of Darwin (1910). Among them was animal physiologist and Nobel Prize winner Ivan Pavlov, who had planned to become a priest until he encountered Darwin's ideas as a seminary student. Prominent as well was Kliment Timiriazev, a highly esteemed plant physiologist who championed Darwin's ideas early on and who was widely known as "Darwin's Russian bulldog," a counterpart to British comparative anatomist T.H. Huxley. ${ }^{40}$

Russian Marxists-members of the Russian Social Democratic Labor Party-were proponents of evolutionary science as well. Among these, Georgi Plekhanov stood out in his belief that Darwinism and Marxism were allied for the cause of the working class. He echoed Engels's graveside eulogy in his description of the achievements of Marx and 
Darwin: "Darwin succeeded in solving the problem of the origins of plant and animal species in the struggle for survival. Marx succeeded in solving the problem of the emergence of different types of social organization in the struggle of men for their existence. Logically, Marx's investigation begins precisely where Darwin's ends." 41 While Plekhanov insisted that different types of laws prevailed in social and biological evolution, other Russian Marxists attempted to creatively apply a Darwinian model to human society. Thus did physician and early Bolshevik A. A. Bogdanov argue that "social forms represent adaptations in the same sense and to the same degree as all biological forms." 42

The Russian Bolsheviks whom American creationists were most likely to target in the 1920s were Lenin and Trotsky. Born Vladimir Ilyich Ulyanov in 1870, Lenin was baptized into the Russian Orthodox Church but grew up influenced by his mother's heterodox religious views and the revolutionary activism of his brother Alexander. The regime executed Alexander in 1887 for a failed attempt to assassinate Czar Alexander III. Around this time, Vladimir Ilyich renounced his belief in God and joined a series of revolutionary groups. Over the next decade, he was exiled to Siberia, and then traveled in Western Europe, debating strategy, exchanging views, writing, and gathering his forces for a coming Russian revolution. A published 1894 polemic against a leading Russian populistN. Mikhailovskii-was one of the rare occasions during this period on which Lenin explicitly addressed the subject of evolutionary science. Mikhailovskii had compared Marx's Capital to Darwin's work and found the former wanting. ${ }^{43}$

In his response to this critique of Marx, Lenin chided Mikhailovskii and his fellow populists for their inconsistency in applauding Darwin's scientific achievement but denying that sociology could be scientific. In contrast with the Russian populists' utopian notions of the ideal society built upon their idealist conception of "human nature," Lenin argued that Marx had provided a much more objective (and materialist) grounding, and in this respect was similar to Darwin:

Just as Darwin put an end to the view of animal and plant species being unconnected, fortuitous, "created by God" and immutable, and was the first to put biology on an absolutely scientific basis by establishing the mutability 
and the succession of species, so Marx ... was the first to put sociology on a scientific basis by establishing the concept of the economic formation of society as the sum-total of given production relations, by establishing the fact that the development of such formations is a process of natural history. ${ }^{44}$

Marx, like Darwin, had discovered a scientific "law of motion."

A debate between Bolsheviks led Lenin, fifteen years later, once again to visit the relationship between biological and social evolution. In Materialism and Empirio-Criticism (1909), Lenin squared off against A. A. Bogdanov, who was working to combine Marxist ideas with recent development in science, including Darwinian biology. Bogdanov had been influenced strongly by two German scientific thinkers: physicist Ernst Mach and chemist Friedrich Wilhelm Ostwald. Best known for his pathbreaking research into vision (including the physics of optical illusions) and acoustics, Mach wrote a number of works that sought to lay a foundation for unifying all the sciences on a solid empirical and non-metaphysical basis. In doing so, however, he adopted a "phenomenalist" stance that required scientists to base their conclusions exclusively on "sensations" and that rejected any attempt to establish a correspondence between such sensations and an "external" world. ${ }^{45}$ For his part, Ostwald had developed a theory of "energetics," which held that energy, not matter, was the single unifying entity in nature. Not only did he argue that energetics could unite all the physical sciences, but Ostwald developed his ideas into a full-blown worldview that encompassed the humanities, social sciences, ethics, and morality. ${ }^{46}$ Since all these ideas emerged when new developments in radioactivity and electrodynamics (and soon to include relativity theory) were exploding previous conceptions of "matter," Lenin was deeply concerned. "Machism" might open the door to a rejection of materialism and the fundamentals of Marxism, all in the name of science. ${ }^{47}$

Like his earlier polemical response to Mikhailovskii, Lenin's Materialism aimed to clarify the position of genuine Marxism. While most of his fire was directed at the fundamental philosophical issue of whether or not there was an external reality, Lenin also addressed the issue of evolution. Among the passages from Bogdanov's writing that Lenin singled out for scorn was the following, which he put in italics: "Every act of social selection represents an increase or decrease of the energy of the social complex concerned. In the former case we have 'positive selection,' in the 
latter 'negative selection." Lenin's reply: "And such unutterable trash is served out as Marxism! Can one imagine anything more sterile, lifeless and scholastic than this string of biological and energeticist terms that contribute nothing, and can contribute nothing, in the sphere of the social sciences?" ${ }^{48}$ For Lenin, unlike many leading American socialists, the unique integrity of both Marx and Darwin forbade carelessly mixing them together in one analytical stew.

Lenin also took pains to clarify the Bolsheviks' perspective on religion. In a 1909 article, Lenin acknowledged that Marxism was atheistic; but he warned fellow Bolsheviks about the political dangers of "declaring war on religion." Traditionally, noted Lenin, "fear [of the natural elements] made the gods." The social roots of modern religion, he argued, lie in the feeling of helplessness on the part of working people, in face of "the blind forces of capitalism." The most effective way to reduce the power of religion is to increase workers' sense of power and control over social and political life. Rather than fervently and provocatively "preaching" atheism, Bolsheviks needed to "work patiently at the task of organizing and educating the proletariat." 49

Lenin was picking up where Marx had left off in his contribution to Critique of Hegel's Philosophy of Right (1844). Marx wrote here that religion was "the opium of the people," which emphasizes the way in which it keeps working people passive and inert. But he prefaced this oft-quoted line with the following: "Religious suffering is, at one and the same time, the expression of real suffering and a protest against real suffering. Religion is the sigh of the oppressed creature, the heart of a heartless world, and the soul of soulless conditions." ${ }^{50}$ Since oppressive conditions were the key to the existence of religious belief, in this view, they should be the focus for change. This sage advice would be pointedly ignored by later generations of Soviet leaders.

Nine years Lenin's junior, Lev Bronstein (1879-1940), later known as Leon Trotsky, was also a dedicated evolutionist. Born into a prosperous Jewish farming family in the Ukraine, Trotsky spent a short time at Hebrew school and then was sent to study in Odessa, which opened his eyes to the wider world. By 1896, he was organizing workers as a populist revolutionary. Arrested in 1898, Trotsky was to serve four years in exile in Siberia, but not before serving some time in an Odessa prison, from which he took both his name (after a jailer) and inspiration from 
reading books. ${ }^{51} \mathrm{He}$ initially had access only to prison-provided Russian Orthodox texts, but soon gained access to books from the outside. Among these were works by Mikhailovskii, Plekhanov, Italian Marxist Antonio Labriola, and Darwin, who made a special impact. When Trotsky entered the prison, he had been attracted to Marxism but had still resisted its lure. "Darwin," Trotsky recalled, "destroyed the last of my ideological prejudices." The young revolutionary left the Odessa prison for Siberia with a new sense of certainty. The "idea of evolution and determinism," he wrote, "took possession of me completely." Darwin, Trotsky told Max Eastman, "stood for me like a mighty doorkeeper at the entrance to the temple of the universe." 52

Nearly two decades later, at the helm of the new Soviet republic, Trotsky and Lenin continued to promote Darwinism along with their Marxist politics and philosophy. The early Bolshevik regime sponsored a vast expansion of Russian science, including the new field of genetics. The People's Commissariat of Enlightenment (known as "Narkcompros") carried out a massive campaign to popularize Marxist ideas. Its Main Scientific Council included as a member Kliment Timiriazev, whose 1919 article "Darwin and Marx" emphasized the parallels between the two men who "marched under the banner of the natural sciences." In 1922, Engels's works on natural science-Dialectics of Nature and "The Role of Labor in the Origin of Man"-were for the first time translated into Russian. ${ }^{53}$ Influential speeches and articles by both Lenin and Trotsky addressed the connections between Marxism, Darwin, and the other natural sciences. In Under the Banner of Marxism, Lenin called for fellow communists to forge an alliance with noncommunist but materialist Soviet scientists. $^{54}$

More so than Lenin, Trotsky directly addressed himself to Darwinian evolutionary science in the early 1920s. In a 1923 article, Trotsky focused on the process by which young people became effective revolutionists. They faced not only external obstacles, but internal ones that inhibited their full commitment to changing the world. The potential revolutionist needed to shed any kind of "mysticism or religious sentimentality." Anyone who "believes in another world," wrote Trotsky, "is not capable of concentrating all his passion on the transformation of this one." Darwinism played an essential role in helping young people lose their belief in another world, argued Trotsky, and thus was "a forerunner, a preparation for Marxism.” Taken together, Darwinism and Marxism could explain 
universal development of nature and society in their proper relationship, from "the living flow of being in its primeval connection with inorganic nature" to the modern class struggle. ${ }^{55}$

To those who claimed that Darwinian gradualism was incompatible with the Bolsheviks' revolutionary politics, Trotsky followed the logic laid out by Arthur Lewis fifteen years earlier. Trotsky acknowledged that natural history included long periods of "relative equilibrium" where species remain "relatively stable" and natural selection operates "almost imperceptibly." But then, on an evolutionary timescale, there are also periods of "geobiological crisis," during which natural selection works with "ferocity" to destroy whole species. Evolution, he concludes, is the "theory of critical epochs" in the natural world, just as Marxism is focused on such periods in the history of human society. Though they would soon be on opposite sides of the deadly factional politics of Stalinism later in the decade, Bolshevik leader Nicolai Bukharin agreed with Trotsky on this point. Contrary to the oft-quoted Latin aphorism, he wrote, in 1925, "Sudden leaps are often found in nature." Our failure to recognize this fact reflects our fear of sudden social shifts, that is, "fear of revolution." ${ }^{56}$

The Bolsheviks' embrace of evolutionary science was sincere, but it also served the practical purpose of undermining traditional religious belief, a process they viewed as essential to building a new socialist society. The early revolution's confrontation with organized religion took several forms, all of which would feature in anticommunist writings in the coming decades. The Russian Orthodox Church was its largest and most lasting target. It was not only tied organically to the czarist regime- the czar was head of state and church-but it permeated Russian culture. In the vast rural areas of Russia, the church, its icons, its rituals, and its network of local priests were deeply enmeshed in the rhythms of daily life. To be effective, a campaign against "religious belief" meant something approaching total cultural war.

A series of decrees issued after the Bolsheviks took power set the stage. They established legal separation of church and state, which meant that control of education as well as all church property now belonged to the Bolshevik regime. No minor could legally receive a religious education, except in a private home. Marriage became a civil relationship. State subsidies to any church institution were suspended. Military clergy were dismissed. At the same time, new positive rights were established. The state 
could pass no law that restricted freedom of conscience or privileged any particular religious belief. More straightforwardly, "Every citizen may confess any religion or profess none at all." ${ }^{57}$

It was one thing to make declarations, and quite another to enforce them. The ensuing civil war both enabled and hobbled enforcement. The decision of Tikhon, the Orthodox patriarch, to ally himself and the church hierarchy with the counterrevolutionary Whites gave the Bolsheviks license to use force to seize church buildings and land and to take harsh measures against bishops, priests, and believers who actively resisted. Bloodshed attended further attempts after the civil war to requisition church treasures to convert to badly needed hard currency. The very militancy of the Bolshevik response emboldened resisters, and led to further reprisals, which undermined any attempt to peacefully convince workers and peasants of the new materialist worldview.

A coercive, administrative, and in some cases extralegal antireligious campaign is not what Lenin himself had counseled in the years before the Bolsheviks took power. Along with their sometimes violent confrontations with church leaders, the Bolsheviks created a whole series of propaganda vehicles-films, traveling drama troupes, mass atheist organizations, and magazines aimed at enlightening the masses. Among the best known was Science and Religion, founded in 1922 and then renamed Bezbozhnik (Godless). A Society for the Friends of Bezbozhnik was soon formed, which, in the left-turn of the "Great Break" of 1928, became known as the League of the Militant Godless. The popular campaigns in support of Marxist-Darwinism fit into this broader antireligious campaign. So did plans to advance the application of science to the lives of Russian peasants. Pushed with special zeal by Trotsky, the materialist calculus suggested that the most powerful way to change thinking was to transform the material conditions of life. The Friends of Bezbozhnik in Samara illustrated this logic by confiscating church bells, selling them, and then purchasing tractors for local peasants. ${ }^{58}$ Despite the wild exaggerations of later anticommunist conspiracy theorists, Bolshevik support for evolution and opposition to the organized power of religion were very real.

That support also inspired one truly bizarre venture that later produced fodder for creationists. The Bolshevik commitment to evolutionary science became international news in 1926 because of a controversial research 
project in Kindia, Guinea (then part of French West Africa), at a facility of the Louis Pasteur Institute of Paris. The lead researcher was Ilya Ivanovich Ivanov (1870-1932), an evolutionary zoologist who had pioneered the practice of large-scale artificial insemination with purebred horses. His project was to artificially hybridize humans and apes. ${ }^{59}$ As strange as the scheme sounds today, the idea had been taken seriously by leading European scientists in France, Germany, the Netherlands, and Russia. Recent discoveries of hominid fossils, as well as living gorillas, fired a popular and scholarly interest in humanity's origins. ${ }^{60}$ While Ivanov and the Bolsheviks did not motivate the project using racist terms, the colonization of West Africa and prevailing racist conceptions of a lower "African" race made the scheme sound reasonable to Europeans. Moreover, the preceding decades had seen a European vogue in the science of rejuvenation. The supposed virilizing powers of ape sexual glands fueled an interest in collecting specimens of live orangutans, gibbons, and chimpanzees. ${ }^{61}$ Successfully appealing to the Bolshevik government for initial funding, Ivanov stressed the project's ability to aid the ideological campaign against organized religion and for Darwinism. In later discussions with the Academy of Sciences-which refused to support Ivanov's work-he stressed the scientific value of his research for human evolutionary studies. ${ }^{62}$

Once in Guinea, Ivanov did carry out at least part of the experimentartificially inseminating several captive chimpanzees with the sperm of a local Guinean man. When the animals failed to become pregnant, the researchers sought to try their luck inseminating local African women with chimpanzee sperm (hoping to do so without the knowledge of the women, who were patients at a French colonial hospital). But the French authorities denied permission. When Ivanov complained about this to his Soviet sponsors, they ordered him not to attempt to impregnate women without their consent. One important legacy of the entire venture, however, was a primatological nursery in Sukhumi, in the Soviet Republic of Abkhazia (later Georgia), where Ivanov continued his work in the late 1920s, soliciting Soviet women volunteers for artificial insemination. Hybridization failed, but the population of chimpanzees gathered at Sukhumi would later produce the animals that rode Sputnik flights into outer space. Those voyages spurred Americans to strengthen scientific education, unintentionally inciting a backlash of creationist activism in the 1960 s. ${ }^{63}$ 
Many Americans became aware of Ivanov's work because of prominent coverage in the US press. In June 1926, a Time magazine titled "Men and Apes" reported that "Ivanoff," supported by Moscow, was headed to Africa to "“support' Evolution by breeding apes with humans.” Readers also learned that the American Association for the Advancement of Atheism (AAAA), led by Charles Lee Smith, was publicizing the project and actively raising funds for it, though Ivanov's staff in Moscow disclaimed any connection with the group. That may well have been because leaders of the AAAA had absorbed the "scientific" racist ideas of British anthropologist F. G. Cruikshank. His artificial breeding scheme recommended the following pairings: orangutans with the "yellow race," gorillas with the "black race," and chimpanzees with the "white race." ${ }^{64}$ But the basic story, as expressed in two June 1926 New York Times headlines, was true: "Russian Admits Ape Experiments" and "Soviet Backs Plan to Test Evolution."65

We do not know whether the refusal of Bolshevik authorities to sanction Ivanov's plans for the secret insemination of African women with ape sperm was based on a principled feminist stand or a matter of realpolitik. We do know that the young Bolshevik regime took unprecedented steps during these years to advance the status of women in revolutionary Russian society. ${ }^{66}$ These controversial measures were reported-and misreported-widely in the United States. The Bolsheviks' record-and its impact in the US-became intertwined with the American debate over evolution during the 1920s.

While the leaders of the Bolshevik Party were overwhelmingly male, and hardly free of prejudice against women, they distinguished themselves in the early years of the revolution by acting on the analysis of women's oppression developed by Engels and Bebel. Women workers, party activists, and soldiers played a critical role in both phases of the 1917 revolution and the ensuing civil war. Once the Bolsheviks took power, they did not hesitate to move forward on this front. Among those leading the charge was Alexandra Kollantai (1872-1952), who like American socialist Lena Morrow Lewis believed that marriage and the patriarchal family were products of an exploitative, class-based society, and that under communism, new forms of human relations and social organization would evolve. ${ }^{67} \mathrm{~A}$ member of the Bolshevik central committee during 
the October revolution, Kollantai became the Bolshevik commissar for social welfare. Along with Inessa Armand, she founded the Zhenotdel, the Women's Department of the Russian Communist Party, from which she fought to change the conditions of Russian women's lives. In short order, divorce was made incomparably easier for women to obtain. Marriage became a civil legal relation, rather than one governed by the Russian Orthodox Church. Abortion was legalized, women gained the legal right to keep their maiden names, and the new regime offered a generous maternity leave policy. And it sought to combat what Lenin referred to as the "barbarously unproductive, petty, nerve-racking, stultifying and crushing drudgery" of the kitchen and nursery. Within the limits of a backward country devastated by civil war, the Bolsheviks pushed forward to build public laundries, cafeterias, and child care centers. ${ }^{68}$

These pioneering measures garnered close attention from both feminists and antifeminists in the United States. ${ }^{69}$ The "information" that most Americans received, however, took the form of sensationalized newspaper stories about the "nationalization" of Soviet women. ${ }^{70}$ The earliest report came in an Associated Press story printed around the United States on October 26, 1918. In Indiana, for instance, the Huntington Press bore the headline, "Decree Provides Maidens Become Property of State." A subheadline in the New York Times informed readers that "Decrees Compel Them to Register at 'Free Love Bureau' on Attaining 18 Years." 71

The US Senate's Overman Committee amplified this coverage. Originally established to investigate pro-German propaganda in the US brewing industry during World War I and chaired by Senator Lee Slater Overman (D-NC), the committee targeted the American communist movement after the war ended. ${ }^{72}$ Committee hearings held in February and March 1919 were sparked by a public meeting that featured Louise Bryant, radical journalist and wife of US Communist John Reed, who had spent time living in the new Soviet republic. She defended the Bolshevik Revolution, including its actions to liberate Soviet women. While Bryant denied the validity of the "free love" charges at the hearings, others deepened the accusations. A former US Commerce Department agent read into the record the text of several documents seemingly proving that the Bureau of Free Love and the nationalization of women were real. A proclamation of the "Anarchist Soviet" of the southern Russian city of Saratov lamented that the "best species of all the beautiful women had been the property of the 
bourgeoisie." To correct this, all women ages eighteen to thirty-two would become the "property of the whole nation." Any man bearing a certificate that he was a member of the working class was entitled to "use" one woman no more than three times a week. Such men were obligated to pay a monthly fee, out of which the women would receive a monthly salary. If a woman were to become pregnant as the result of her "use," the child would be given up to an "institution" at the tender age of one month. ${ }^{73}$ This, then, was social evolution, Soviet-style.

The reality behind the Saratov decree and similar documents is difficult to discover. They emerged in the "fog" of a civil war between the Bolsheviks and the Whites, whose troops were joined by fourteen nations, including those of Britain and the United States. There was a rich history of fabricated documents in the drama of the Russian Revolution going back to the 1903 Protocols of the Elders of Zion. ${ }^{74}$ There is evidence suggesting that the Saratov document was fabricated by a local monarchist to put the anarchists in a bad light. From there, the proclamation took on a life of its own, either in the hands of White generals looking to win peasants away from the Bolsheviks, or by anarchists who truly believed that the new socialist utopia included some version of "free love." Just as the Greenwich Village-based Socialist bohemians in the US placed more emphasis on women's sexual liberation than did the mainstream of the party, so did a small minority of the victorious revolutionaries in Russia aim to make dreams of a new sexual order a reality. ${ }^{75}$ It is unlikely such schemes represented Bolshevik policy. In at least one case, when Lenin learned of a plan to "redistribute" women in a town in his native region of Simbursk, he sent an angry telegram, ordering the local Cheka to investigate and, if the rumors were true, to "arrest the guilty."76

Despite political factionalism, ongoing scientific debates, questionable hybridization schemes, and fabricated Free Love Bureaus, the authority of evolutionary science in the new Soviet Republic was largely untarnished. Debates over the mechanism of evolution presumed that evolution was a fact. In April 1932, on the fiftieth anniversary of Darwin's death, Soviet authorities carried out a broad campaign to celebrate Darwin's heritage. One prominent headline read, "The Working Class, Armed with MarxistLeninist Theory, Takes Everything Truly Scientific from Darwinism for the Struggle to Build Socialism." According to a new popular slogan, "The Soviet Union is the second birthplace of Darwin." In contrast, as another 
headline pointed out, in the United States, or rather, "countries of dying capitalism and rotting bourgeois culture," Darwinism was "on trial as the accused." 77 In this early "cold war" over evolutionary science, the Soviets were clearly in the lead.

Back in the United States, the homeland of "dying" capitalism, a tiny but energetic communist movement also took up Darwin's banner. In 1919, former members of the left wing of the American Socialist Party, inspired by the Bolshevik Revolution, broke off to form two fledgling communist parties-the Communist Labor Party and the Communist Party of America. Joining the Communist International, the American organizations were fundamentally different from the former Socialist Party. Not only did they espouse a revolutionary outlook on how workers would reach a socialist future, but they built a new kind of party based on the Leninist model. This would be a disciplined, politically homogeneous organization that left behind the "big tent" approach of the Socialist Party. ${ }^{78}$

The Bolsheviks' American comrades were in a poor position in the mid1920 s to make an impact on the raging debate over evolution. The majority of them did not speak or publish in English. They tended to adopt an unrealistic "ultraleft" perspective that revolution was just around the corner. Owing to the post-World War I red scare, the parties remained underground for several years, emerging as an open, legal organization, the Workers Party, only in 1921. It took a determined fight by one faction, known as the "Liquidators," to convince Comintern leaders and the ranks of the party that it was time to start conducting politics openly. As soon as that question was settled in their favor (and against the "Goose" faction, who were fonder of the underground party), factional divisions quickly developed along other fronts. For the entire decade, the tiny American communist movement-numbering somewhere fewer than twenty thousand-was virtually at war with itself. ${ }^{79}$ It was not until 1923 that a single united party emerged—awkwardly designated the Workers (Communist) Party. ${ }^{80}$

But once the nation's attention was riveted on State of Tennessee $v$. John Thomas Scopes, in the summer of 1925, the American communists jumped into the fray. The Daily Worker was full of coverage that clarified the stakes for workers and the communist movement in the battle in Dayton, Tennessee, and beyond. News articles closely followed daily 
developments in the trial, which lasted from July 10 to July 21, 1925. In the twenty-six days from July 3 to July 29, the Daily Worker ran at least one article on the trial on nineteen of these days. A typical specimen appeared on the front page of the July 14 issue and was titled "AntiEvolution Law Branded Unconstitutional in Fight for Freedom of Education." It contained significant excerpts from a statement given by John Neal, the chief attorney for Scopes, who sought, unsuccessfully, to quash his client's indictment on the grounds that Tennessee's Butler Act was unconstitutional. ${ }^{81}$ While no author's name appeared in the byline-only "Special to the Daily Worker"- the inclusion of visual and aural details such as "the judge looked worried" and "there was a gasp of surprise" suggests that the reporter sending in stories to the Daily Worker was on the scene. ${ }^{82}$

One of the "special" correspondents for the Daily Worker was John T. Scopes himself. On July 21, the day the jury convicted him of violating the Butler Act, Scopes filed a brief story about continuing the fight. He reviewed the factors militating against a victory in Dayton, but looked forward to winning the case on appeal. "We will stay by the ship and every point will be fought out bitterly," he wrote. "Success is ultimately with us." The same exact story appeared elsewhere as an "exclusive" for Hearst's International News Service-throwing into question what the appearance of the article in the Daily Worker signifies. But given what we know about Scopes's political upbringing, it is entirely possible that he would have had no objection to his words appearing under the Communist banner. ${ }^{83}$ At the very least, John Scopes knew that the radical labor press took up a wide variety of social issues and related them to the struggles of working people.

The Daily Worker spelled out how evolution was relevant to workers in a variety of ways. In "Darwinism on Trial," published the day the trial opened in Dayton, the editors commented on what they viewed as a conflict between two wings of the American "bourgeoisie." Even though this was a fight within the ranks of the "class enemy," they wrote, "the working class cannot remain an idle onlooker." To the contrary, workers needed to realize that Darwinism was part of the Marxist worldview, the "Communist conception of the universe." Both Marx and Darwin had overturned the concept that the existing order, either social or natural, was immutable and had resulted from "eternal laws." When workers 
began to understand that capitalism was not eternal, they would move toward socialist revolution.

While the Communists defended evolutionary science, they also sought to expose unnecessary compromises made by pro-evolutionists. For the Daily Worker, the guilty parties included the Socialist Party, whose Milwankee Leader ran an editorial in July 1925 titled "Evolutionists Defend Religion." "This paper is not irreligious," wrote the Milwaukee Socialist editors, "and it never attacks religion, either expressly or impliedly." The Socialists continued to hold a variety of views of religion, while the Communists, made up primarily of the former left wing of the Socialist movement, took a clearer atheist stand.

The compromisers also included Clarence Darrow. While the Communists supported Darrow as against Bryan, another editorial portrayed both as representatives of the "middle class." Darrow was the "middle class intellectual," and Bryan was "the leader of the well-to-do farmers of the middle west and south" whose interests were opposed to big capital. As a middle-class figure who found himself hemmed in by opposing classes, Darrow consequently waffled on evolution by refusing to take a clear atheist stance. As the editors put it, "Only the Communists stand squarely against religion as 'the opium of the people." ${ }^{84}$ This distinctive Communist critique of middle-class pro-evolutionism was reflected in Monkey or Man? (1925), a satirical play composed by Mike Gold. Gold was a Communist activist and well-known exponent of "proletarian literature," a Bolshevik-inspired genre of Marxist-infused fictional writing based on the lives of working-class people. ${ }^{85}$ According to the Daily Worker, Gold's play was “a characterization of the struggle that is taking place between the Fundamentalists and the Modernists. It will show them both up." 86

Despite the way in which the Communists seemed to say "A plague on both your houses," they reserved a special level of venom for William Jennings Bryan. Not only was Bryan the leading voice of the fundamentalists on the issue of evolution, but he had falsely portrayed himself for decades as the champion of workers and farmers. One line of attack portrayed Bryan as an ally of the Ku Klux Klan in its campaign against evolution and for fundamentalism. Bryan was, one article claimed, "the most perfect type of kluxer." In the wake of Bryan's death, another article argued that Bryan had literally been "a member of the 


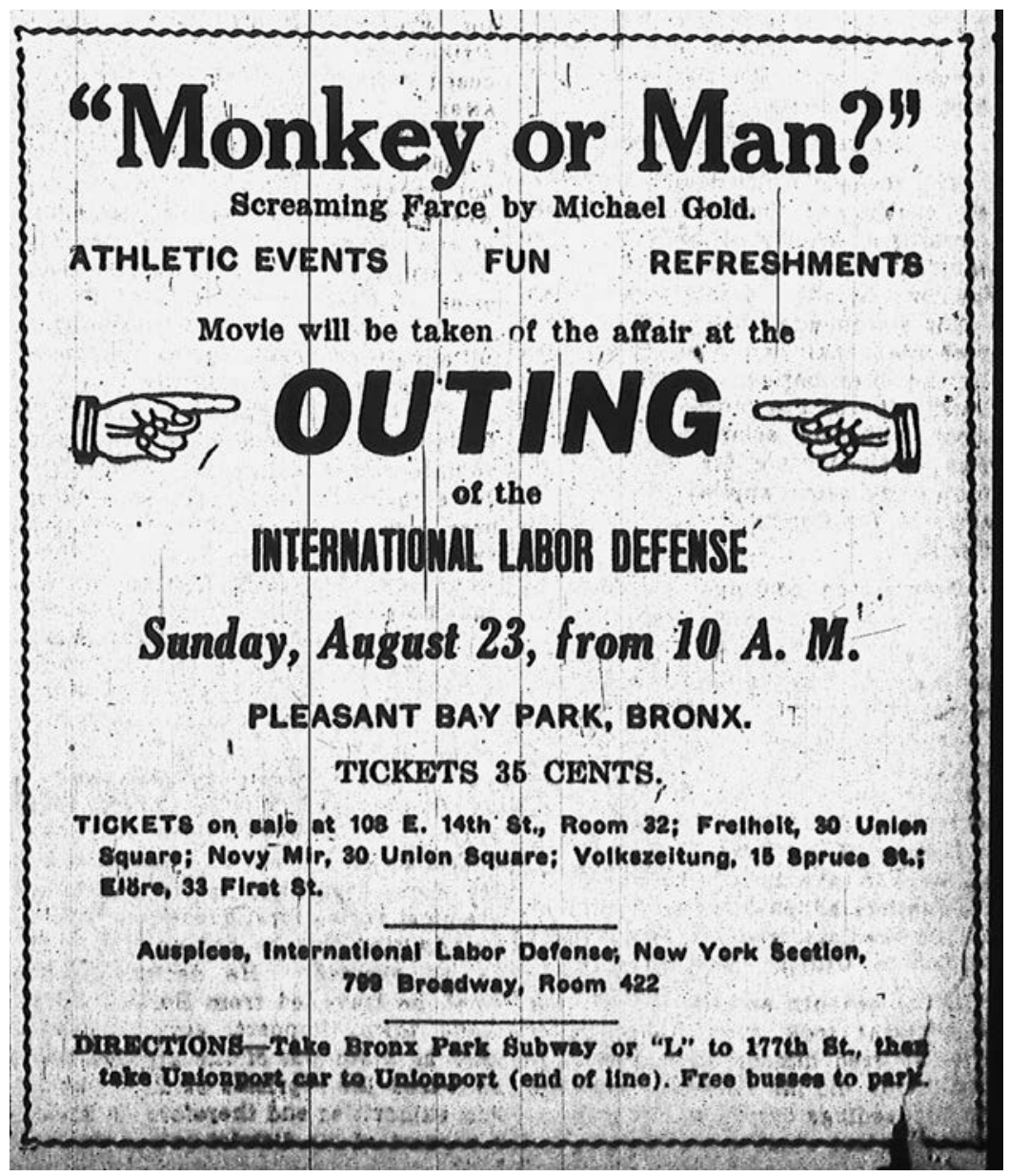

Figure 3. Advertisement for an International Labor Defense picnic, 1925. Just weeks after the Scopes trial, a performance of the satirical evolution-themed play Monkey or Man? formed the centerpiece of this event sponsored by the International Labor Defense, a Communist Party-organized united-front group. The early Communists gave an uncompromising defense of evolutionary science. Daily Worker, August 20, 1925.

ku klux klan.” The evidence was drawn from publicity for an upcoming Klan gathering, the stated purpose of which was to seize "the torch of fundamentalism from the falling hand of Bryan and carry it aloft in national conflict." ${ }^{87}$ While this was hardly conclusive evidence, Bryan knew 
that the Klan played a powerful role in pushing forward antievolution laws. Whatever his qualms about Klan tactics, he led a successful fight at the marathon 1924 Democratic National Convention against including a plank in the party platform explicitly denouncing the hooded order. And like most leaders of the Democratic Party, Bryan publicly proclaimed the idea-and defended it against prominent African American critics-that whites were "the advanced race." 88

Another contribution of the Communists was their confidence that evolutionary science would prevail. That attitude stemmed from their Marxist standpoint on the relationship between capitalism, scientific progress, and the working class. In a Daily Worker editorial reiterating the point Arthur M. Lewis had made years earlier, party leader William Schneiderman argued that those fighting against the advance of science are doomed to fail. The editorial was illustrated by a Soviet political cartoon mocking Americans. Reprinted from Komsomolskaya Pravda, it depicted a Tennessee legislator as a "monkey" and was captioned, "Living Proof of Darwinism." Such characters could not succeed, Schneiderman explained, because the capitalists themselves need science in order to revolutionize production. By promoting scientific thinking among the workers, the capitalists inevitably and unwittingly erode "the superstition and ignorance upon which the bourgeoisie depend to maintain their strangle hold on the toilers." 89

Promotion of scientific thinking among workers-deliberately by communists or unwittingly by capitalists—was all but impossible, according to the best-known journalistic commentator on the Scopes trial, H.L. Mencken. Known for his original style and biting satirical wit, Mencken was also deeply elitist and antidemocratic, as Daytonians quickly discovered. In a Baltimore Sun column titled "Homo Neanderthalis" published on the eve of the trial, the journalist insulted the intelligence of Dayton "yokels" by claiming that they would and could never understand scientific ideas. "It would be as vain to try to teach to peasants or to the city proletariat," Mencken wrote, "as it would be to try to teach them to streptococci." The working people of East Tennessee, that is, were no brighter than bacteria. ${ }^{90}$

In contrast to Mencken, and armed with their revolutionary confidence in the capacities of ordinary working people, the Communists took to the streets to reach them with a pro-evolution message. Readers of the 
Daily Worker learned that Communists planned an "open air meeting” in Minneapolis, William Bell Riley's home turf. Workers (Communist) Party organizer John Gabriel Soltis was projected to speak on the "Principles of Evolution and the Working Class." At a Chicago Communist meeting, party members voted to "organize as soon as possible a mass meeting on the Scopes trial, in order to bring out the attitude of the Communists toward religion and science." 91 Area communists were experienced street speakers. Two weeks earlier, Communists J.K. Dante and Irving Search had been speaking in neighboring Cicero, where the Workers Party held weekly street meetings. This time, however, "a gang of sluggers, led by a priest, attacked the meeting and tried to break it up." Rather than corral the attackers, police arrested Dante and Search. At their trial, the city prosecutor mentioned the Scopes trial and proclaimed that he would protect the residents of Cicero from "heresy." 92 The judge dismissed the charges, but the dangerous mixture of evolution and communism was in the Chicago air.

Two very different American communists, a preacher and an editor, are worthy of note for their sustained focus on evolutionary science. In late June 1925, on the eve of the Scopes trial, when Chicago Communists hosted a meeting launching the International Labor Defense, the speakers' rostrum featured not only central party leaders and leftwing Socialist veterans such as Benjamin Gitlow and James P. Cannon, but a relative newcomer to the party who had spoken out in support of both evolution and communism: William Montgomery Brown (1855-1937). ${ }^{93}$ Serving as bishop of Arkansas in the Episcopal Church, Brown had developed unorthodox views under the impact of books by Darwin, Haeckel, various Christian Socialists, and the German monist philosopher Paul Carus. In 1920, he self-published a quirky procommunist tract, Communism and Christianism: Analyzed and Contrasted from the Marxian and Darwinian Points of View. Brown soon joined the Workers Party. In 1924, using quotations from Brown's book, the Episcopal Church tried the "Bad Bishop" for heresy and officially deposed him the following year. ${ }^{94}$

The motto of Communism and Christianism, printed on the book's cover, called on its readers to "Banish Gods from Skies and Capitalists from Earth.” Featuring portraits of Marx, Engels, Darwin, and Lenin, 
Brown's book included generous quotations from the Communist Manifesto, Charles Kerr's Scientific Socialism Study Course (presented as a catechism), and Socialist Party platforms, along with his distinctive prose. Brown focused on what he called the "twofold revelation" of Marxism and Darwinism, which together constituted the truth (referred to in John 8:32) that "shall make you free" from "commercial imperialism" and its attendant "unnecessary suffering." As in this passage, the book used religious language and biblical quotations in the service of proletarian revolution and modern science. "Darwinism and Marxism," wrote Brown, "constitute ... the only, true, comprehensive, and sufficient gospel" that would lead to the "salvation" of humanity through Bolshevism. The Soviet regime translated Brown's book into Russian and used it during the 1920s to erode the authority of the Russian Orthodox Church. ${ }^{95}$

Last but hardly least in the efforts of early Communists to spread the gospel of evolution was the indefatigable Ludwig Katterfeld (1881-1974). He edited and published Evolution: A Journal of Nature, the very first popular-oriented monthly magazine in the United States to promote the cause of evolutionary science. ${ }^{96}$ Though Katterfeld and his little magazine have been largely forgotten, he was a central figure in the radical movement. As a member of the National Executive Committee of the Socialist Party, he helped lead the party's opposition to US entry into World War I. In 1919, Katterfeld became a founding member of the new Communist Labor Party. As the result of the Palmer Raids early the next year, Katterfeld was arrested and stood trial in July 1920 in Chicago for violating the Illinois criminal syndicalism law. Though he and his comrades were defended ably by none other than Clarence Darrow, Katterfeld was sentenced to one to five years in prison and fined \$2,000. While he appealed the conviction, Katterfeld was in the inner circles of the new united Communist Party of America, which twice sent him to Moscow. There he conferred with Lenin, Trotsky, and others about pressing political questions, including the "liquidation" of the underground American party. Upon his return to the US in 1923, Katterfeld served a year in the Illinois state prison at Joliet. When he emerged from behind bars, he moved to New York and managed the East Coast distribution of the Daily Worker. ${ }^{97}$

In 1927, some two years after Katterfeld arrived in New York, he took the initiative to launch Evolution. Present at the creation of this publication 
was a young Communist Party member who later became world famous for his role in the Alger Hiss espionage case: Whittaker Chambers. According to Chambers, Katterfeld started up his magazine when the party faction he supported-the Foster-Cannon caucus-lost out. "When the Lovestoneites took power in the party," recalled Chambers, "Katterfeld withdrew from it. He began to publish a magazine called Evolution, for his mind was in many ways a petrifact of 19 th-century radicalism, and among its oddments of conviction was militant Darwinism." 98 Factional shifts may help explain the timing of Katterfeld's decision. ${ }^{99}$ But the suggestion by Chambers that, in the eyes of proper Communists, "militant Darwinism" was a quaint artifact ignored recent Communist history. Evolution began as a monthly, but by the early 1930s Katterfeld had to suspend publication, only to revive it later in the decade. When he did so in 1937, however, no less than Time magazine ran a substantial story on the reappearance of Evolution, its "mild-mannered" former Socialist editor, and his "crusade for scientific truth."100

As the Time article indicated, Evolution was a remarkable publication on a number of counts. It adopted an in-your-face graphic strategy: the cover of the first issue sported a photo of a gorilla, whose caption read, "Man's Blood Cousin: The Gorilla." As historian Constance Clark has noted of the use of the gorilla in evolution cartoons, these depictions drew upon long-standing traditions in which "these gentle animals often carried sensational, even salacious, metaphoric freight-and racial connotations-in European popular culture." ${ }^{101}$ Knowing this, Katterfeld seems to have chosen this provocative image for precisely this reason-it would get people talking. Talk they did. As the editor reported in the next issue, the cover image "caused comment all over the continent." In his opinion, at least, nearly all of it was "very favorable," although some less radical-minded pro-evolutionists found Katterfeld's methods counterproductive. ${ }^{102}$

Despite its provocative covers, Evolution was avowedly "non-political," meaning, nonpartisan. The magazine's proclaimed purpose was "to combat bigotry and superstition and develop the open mind by popularizing natural science." Regardless of party affiliation, all who embraced this goal could use the information in the magazine for their own purposes. At the same time, Katterfeld specified that the publication, though being "non-religious," would also not be atheist, knowing full well that atheism 
had explosive political implications. ${ }^{103}$ While Katterfeld's was an inherently political venture, there was little indication that the publication's editor was, or ever had been, a central leader of the Communist and Socialist parties. (One clue was the regular appearance in "Some Good Books" offered by the Evolution Book Service of Bishop William Montgomery Brown's My Heresy. $)^{104}$

Given Katterfeld's lack of scientific credentials-and his past conviction for sedition-another striking thing about Evolution is the impressive roster of contributing writers. They included David Starr Jordan, the famed ichthyologist, Darwinist, and emeritus president of Stanford University, who wrote an introductory piece that ran in the magazine's first two issues; William King Gregory, a professor of zoology at Columbia University and staffer at the American Museum of Natural History who was regarded as the world's leading authority on the evolution of human teeth; Hermann J. Muller, who had recently demonstrated the ability of radiation to induce genetic mutations (for which he won the Nobel Prize in 1946); and Harry Elmer Barnes, a Columbia historian deeply influenced by Darwin's ideas in the realm of social evolution. Early praise for the new magazine came from Columbia faculty as well. Philosopher John Dewey congratulated Katterfeld for "enlisting as writers persons of unquestioned competency and having a clear style." "I am impressed," Dewey wrote, "with the fact that the Journal is scientific as well as popular. You are rendering a public service and I wish you every success." 105

As much as Evolution popularized evolutionary ideas, the magazine also helped evolutionists to become better acquainted with their enemies. Each issue featured a "Funnymentals" column that quoted from the likes of Gerald Winrod, William Bell Riley, George McCready Price, and others. Katterfeld was providing a measure of "comic relief" for his readers, who were likely to view as bordering on lunacy this statement from Winrod: "I would rather my babies' eyes be gouged out at this minute than to have them taught this blatant atheism."106

But in other respects, this "humor" column was deadly serious. It provided a revealing look at the arguments fundamentalists were making, thus helping to arm and encourage pro-evolutionists to fight back. In the August 1928 issue, as a battle raged over teaching evolution in Arkansas, Katterfeld printed the full text of Riley's "The Fundamentalist Challenge." He then printed, at the bottom of the page, a call to "ANSWER THIS 
FUNDAMENTALIST CHALLENGE by sending copy of EVOLUTION with Ward article to each of FOUR HUNDRED THOUSAND FAMILIES IN ARKANSAS." (Charles Henshaw Ward, one of the most successful popularizers of evolutionary science, had already contributed several articles to Katterfeld's journal.) 107 "Funny" fundamentalist excerpts also included several that pointed at the confluence of communist politics and evolution. Such was the reprinted Defender cartoon of a bearded, sneakylooking man holding a bomb labeled "Evolution," above the caption "Red Russian Ravages." 108 Whether or not Whittaker Chambers knew it, Katterfeld and his fellow communists were aware that antievolutionism and anticommunism were closely allied.

Of the evolutionary biologists on the roster of Katterfeld's Evolution, the one most likely to appreciate this brand of communist humor was probably Hermann J. Muller (1890-1967), whose story wraps up this chapter. From 1914 to 1918, Muller taught and conducted research at Houston's Rice Institute, where Julian Huxley, famed evolutionist and grandson of T.H. Huxley, had founded the biology program. Recruited by Huxley, Muller continued his work on Drosophila that he had started as a student in the fly lab of famed geneticist Thomas Hunt Morgan at Columbia. But he also developed a new theoretical explanation-based on "lethal mutations"-for the observations of rapid evolutionary leaps in generations of Oenethera lamarkiana made by Hugo de Vries that was consonant with Morgan's Mendelian ideas. ${ }^{109}$ This put him on the road to his work on X-rays and made a significant contribution to what became the modern evolutionary synthesis. But it was the political events of these years-most notably the Bolshevik Revolution-that changed the course of Muller's life. He was already a socialist by 1917 , and he would soon become deeply enmeshed in the politics of science in the Soviet Union.

In 1922, then teaching at the University of Texas, Muller visited the young Soviet republic for the first time. Recalling his visit, Muller appreciated the degree to which evolutionary science was endorsed by the Bolshevik government, providing a "curious commentary" on the state of affairs in the US. Muller's observation emerged from a conversation with a Professor Berg, who conducted research on plant genetics. In his studies of cereal plant evolution, Berg had put forth a theory known as orthogenesis, which meant that evolution moved in a predictable, predetermined 
linear direction. When Muller mentioned that some American states were moving in the direction of banning the teaching of evolution, Berg related that his own book was currently under review by Bolshevik authorities who regarded his idea as "pernicious and subversive." There was potential censorship in both cases. But Berg was in hot water not because he was supporting evolution, but because he was perceived to be undermining it. His book stood outside the new political orthodoxy of MarxistDarwinism, based on the central idea of natural selection. ${ }^{110}$

Muller's conversation captures the sharp contrast between the situation facing evolutionary biologists in the US and USSR in the 1920s. It points as well to the political pressures bearing down on Soviet researchers, which later would prove dangerous for not only their academic futures but their physical existence. Muller found himself on the wrong side of the Stalinist divide in the 1930s when he was living and working in Moscow. ${ }^{111}$ But the later Lysenkoist campaigns against genetics in the Soviet Union have obscured a fact that was evident to observers, including Muller, in the early years of the Bolshevik Revolution: the Communists were outstanding promoters of evolutionary science. Their comrades in the United States were as well. As the next chapter documents, American antievolutionists were paying attention. 